\title{
Journal of Ethnobiology and Ethnomedicine
}

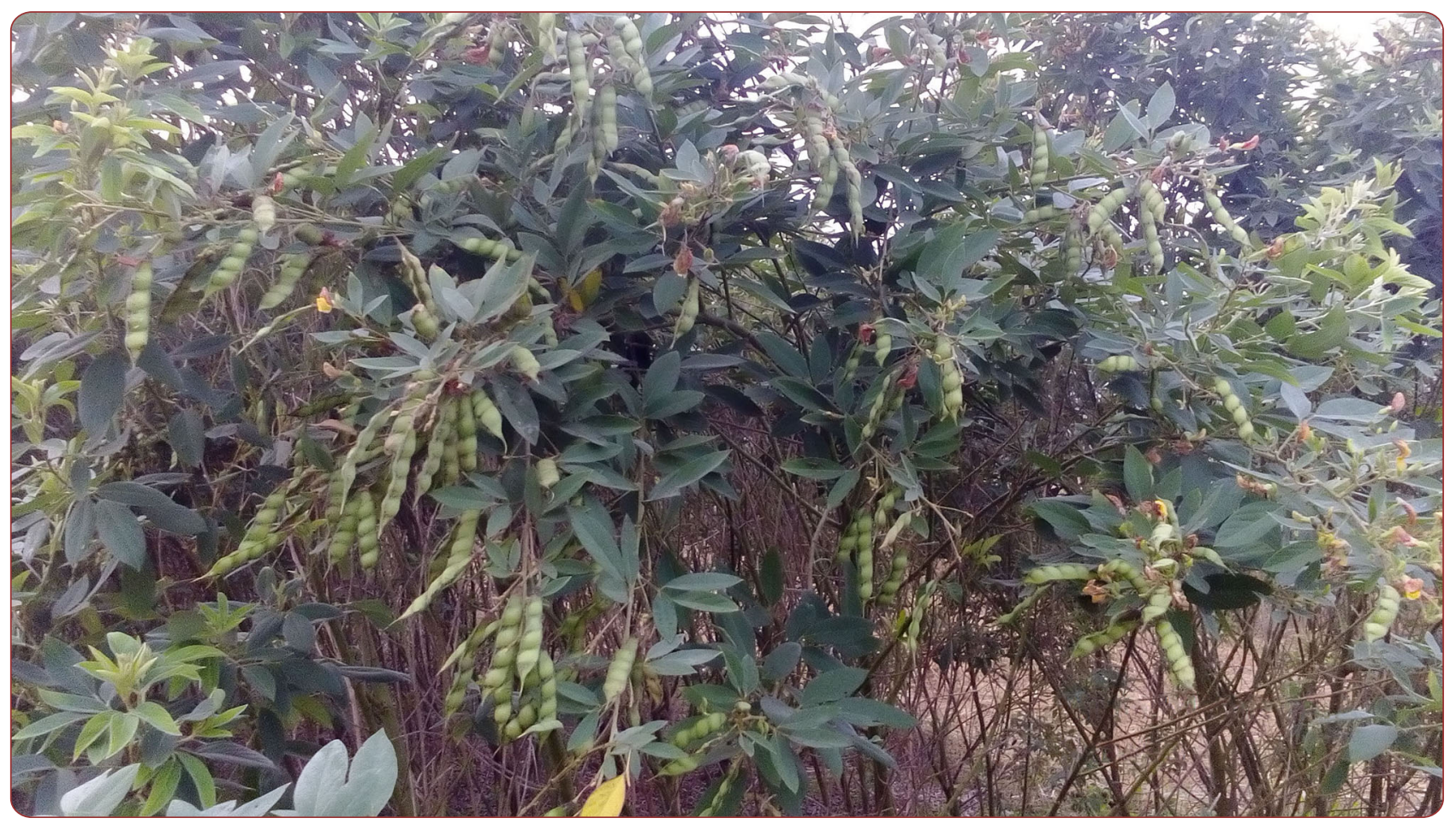

\section{Utilization and farmers' knowledge on pigeonpea diversity in Benin, West Africa}

Ayenan et al. 


\title{
Utilization and farmers' knowledge on pigeonpea diversity in Benin, West Africa
}

\author{
Mathieu Anatole Tele Ayenan ${ }^{1 *}$, Agyemang Danquah ${ }^{1}$, Léonard Essehou Ahoton ${ }^{2}$ and Kwadwo Ofori ${ }^{1}$
}

\begin{abstract}
Background: Understanding factors driving farmers' uses of crop genetic resources is a key component not only to design appropriate conservation strategies but also to promote sustainable production. However, in Benin, limited information is available on farmers' knowledge related to pigeonpea uses and conservation. This study aimed at i) identifying and investigating the different uses of pigeonpea in relation with socio-cultural factors, namely age, gender, ethnic group and respondents' residence, ii) assessing pigeonpea varieties richness at household level and iii) evaluating the extent and distribution of pigeonpea varieties.
\end{abstract}

Methods: Three hundred and two farmers were surveyed using structured questionnaire. Direct observation, field visit and focus group discussion were carried out. Association between number of varieties maintained at household level and socio-cultural variables was tested. Mann-Whitney test was used to assess whether the number of varieties held by households headed by men and women were different. Distribution and extent of diversity was assessed through four cells analysis.

Results: Farmers in Benin mainly grow pigeonpea for its grains for home consumption. Pigeonpea's stem and leaves are used for medicinal purposes to treat malaria, dizziness, measles, and eye infection. The ethnic group and the locality of residence of farmers influenced on the use of pigeonpea for medicinal purposes $(P<0.01)$. There was no significant association $(P>0.05)$ between the number of varieties held by household and the age of the respondent, number of years of experience in pigeonpea cultivation, the size of household, number of family members engaged in agricultural activities and gender. Farmers used criteria including seed colors, seed size, plant height, maturity groups and cooking time to classify their varieties. Varieties with white seed coat color were the most grown while varieties with black, red or mottled seed coat color are being abandoned and deserve to be conserved.

Conclusion: Knowledge on medicinal uses of pigeonpea is vertically transmitted within community and pigeonpea varieties maintenance at household level does not depend on socio-cultural factors. This study will contribute to raise awareness on the various utilization of pigeonpea. In addition, it provides the basis for designing conservation strategies of pigeonpea genetic resources.

Keywords: Cajanus cajan, Folk taxonomy, Four Cells Analysis, Medicinal uses; Symbology

\section{Background}

Crop diversity contributes to increase food security, to alleviate poverty and to protect environment [1-4]. Cultural diversity in a given region is reflected through crop diversity, from which local population source their food and other goods and service to meet their ever-changing needs [1]. In recent years, the link between traditional knowledge and diversity of cultivated plants has drawn

\footnotetext{
* Correspondence: mathieuayenan@gmail.com

${ }^{1}$ Department of Crop Science, School of Agriculture, College of Basic and

Applied Sciences, University of Ghana, P. O. Box LG 44, Legon, Ghana

Full list of author information is available at the end of the article
}

attention and a parallelism has been established between cultural diversity and biodiversity $[5,6]$. Thus, various international agreements including Convention on Biological Diversity, International Treaty on Plant Genetic Resources for Food and Agriculture have emphasized on the contribution of indigenous knowledge in the maintenance of genetic diversity.

Traditional knowledge related to crop diversity includes different usages of crop species, their symbols for community, cultural value of the crop, preferences for cultivars, special recipes associated to the crop and genetic material 
exchange networks and management, songs and folks through which knowledge is transmitted [3, 7-9]. Threats on traditional knowledge related to diversity use and conservation are increasing [10]. Changes occurring in agricultural systems resulting from globalization, urbanization, agro-industrialization and intensification of agricultural systems have led to over reliance on production of few major crops and few elite cultivars [4, 10-12]. Consequently, there is a decline in production and diversity of so-called minor crops, important for food security in marginal areas, and the traditional knowledge associated to their conservation [13]. This rapid decline in diversity of neglected crops species and local knowledge systems related to their uses and management hampers agroecosystems resilience, reduces options for adaptation to changing biophysical conditions and limits the potential to develop improved varieties $[10,14,15]$. Understanding factors driving farmers' uses of crop genetic resources is a key component to design conservation strategies and promote their cultivation and uses [12] notably for the minor or underutilized ones. In this perspective, traditional knowledge on uses and conservation of crop diversity has been documented for many crops (eg: [13, 16-20]).

In Benin, pigeonpea is a source of income and food security for rural household [20]. Despite its role in food security, pigeonpea falls in the category of genetic resources for food and agriculture found in farmers' fields which are still to a large extent inadequately documented and managed $[20,21]$. As such, drivers of uses and diversity maintenance of pigeonpea are still not well understood [20]. This is a threat for pigeonpea genetic resources since new varieties are being introduced in the growing areas (Authors' personal observation). In addition, no systematic collection of pigeonpea genetic resources has been undertaken in the country yet. In order to avoid or limit the extent of genetic and knowledge erosion related production and uses of pigeonpea in the Benin, knowledge on uses and diversity of the crop that is currently held by farmers needs to be documented. Understanding the indigenous knowledge system in a minor pigeonpea growing country like Benin, is vital to advocate the importance of the crop as source of nutrients to cope with food insecurity and to introduce successfully new cultivars based on farmers 'preferred traits [22]. Elsewhere, the investigation of the relationship between farmers' knowledge and crop diversity revealed that various social, economic and cultural factors shaped the uses and the number of crop diversity maintained at community and household level [11, 23, 24]. Thus, crop varieties are considered as social objects [25]. We then hypothesized that socio-cultural factors influence uses of pigeonpea and the number of varieties maintained at household level. More specifically, we assumed that depending on socio-cultural factors such as age, gender, residence and ethnic group farmers may affect farmers' knowledge and access to information regarding the uses of pigeonpea genetic resources. In addition, age, number of years of experience in pigeonpea cultivation, household size, and number of family members engaged in agricultural activities and gender may influence farmers' variety preferences and seed movements which would drive the number of pigeonpea varieties and the kind of varieties farmers maintain at household level. Our study aimed at 1) identifying and investigating the different uses of pigeonpea in relation with socio-cultural factors including age, gender, residence and ethnic group, 2) assessing pigeonpea varieties richness at household level based folk taxonomy and 3) evaluating the extent and distribution of pigeonpea varieties based on farmers' perception.

\section{Methods}

\section{Study area}

The study was conducted in the major pigeonpea growing areas which were identified based on production figures obtained from the Ministry of Agriculture [26]. Data were collected in twenty villages (Fig. 1) spread over four Administrative Departments (Collines, Zou, Plateau and Couffo). In the study area, about $70 \%$ of the population lives in rural areas and agriculture is their major activity. Several ethnic groups and religions are encountered in these areas [27]. Maize, cassava, cowpea, yam, sorghum, rice and oil palm are the main cultivated crops [26] while pigeonpea is one of the minor crops cultivated by small farmers for subsistence and income generating $[20,28]$.

\section{Sampling technique and data collection}

Respondents were selected using the snow-balling sampling technique as described by Biernacki [29]. Three hundred two (302) pigeonpea growers were reached in the growing areas [28]. Pigeonpea growers were $42 \pm 1$ (SD) years old on average with the majority of them (82\%) being between 30 and 60 years old [28]. About $10 \%$ of the respondents were below 30 years old and $8 \%$ were above 60 years. Respondents who were less than 30 years old, between 30 and 60 years old and above 60 years old were considered as young, adult and old people, respectively [30]. Sixty-two percent of the pigeonpea growers were male. The average size of the household was six members among whom three persons on average were involved in agricultural activities [28].

A questionnaire was administered to sampled pigeonpea growers. Prior to the administration of the questionnaire, the objectives of the study were explained to farmers in local language and their informed consent was obtained. The questionnaire was divided into two main sections namely: 1) Uses of different parts of pigeonpea plants (seeds, stems, roots and leaves); 2) name and description of each grown variety, number of pigeonpea varieties held 


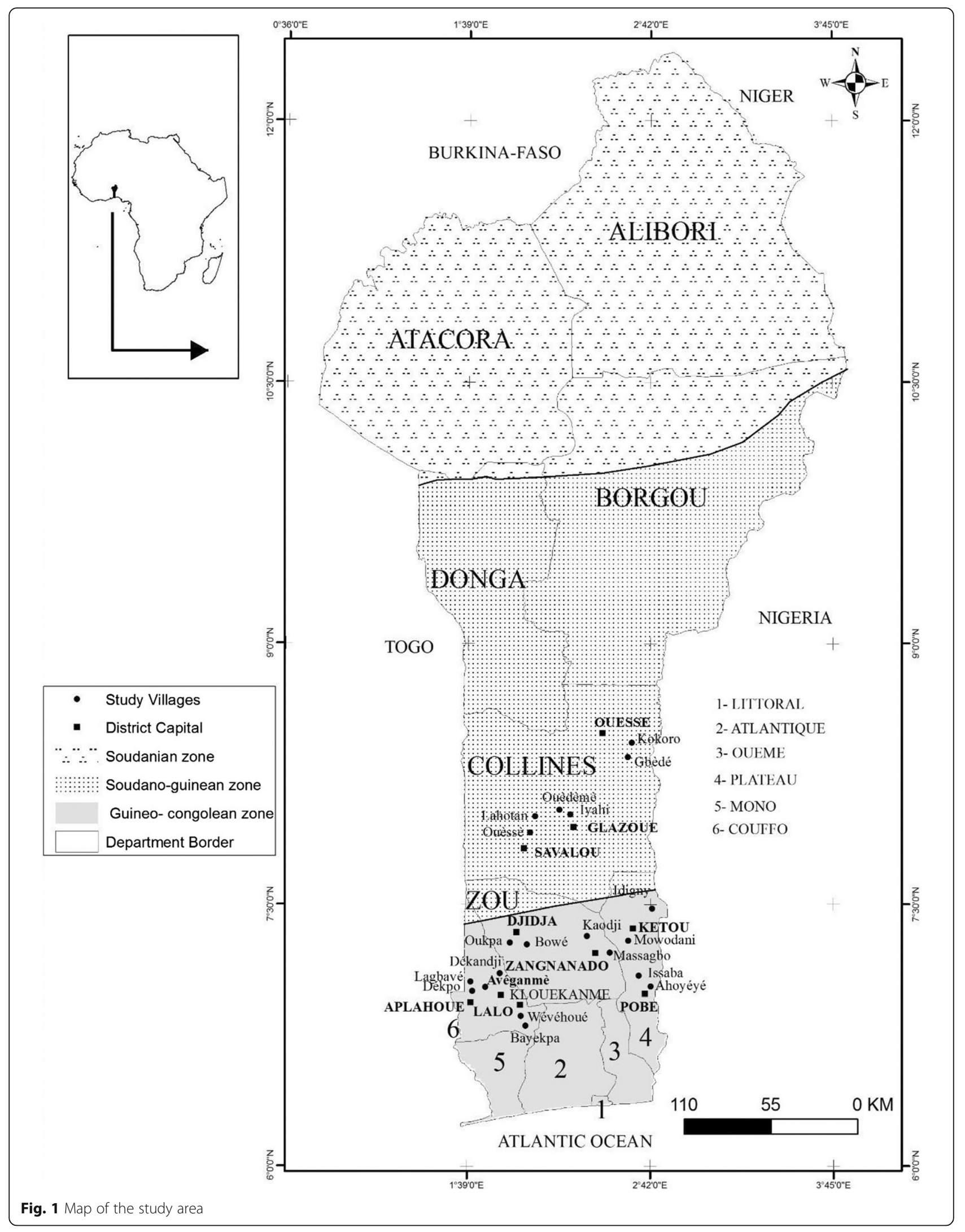


at the household level, desirable and undesirable traits of each variety as perceived by farmers.

In each village, a focus group was held with on average 12 pigeonpea growers including female and male to collect data related to the different varieties of pigeonpea grown and their characteristics. Data related to folk taxonomy, meaning of pigeonpea varieties in the various local languages encountered in the village, the plant's role in ceremonies, or in symbolism were collected. For each cultivated variety in the village, the extent (perceptions of farmers on allocated area to its cultivation) and distribution (perception on the number of household growing the variety) were recorded. This information was used to assess the status of each variety in the village and to draw implications on its conservation.

\section{Data analysis}

Descriptive statistics including frequencies and means were computed to describe quantitative data, namely percentage of respondents for each category of pigeonpea use (home consumption, commercialization and soil conservation) and number of pigeonpea varieties per location and households. We tested whether uses listed by respondents (frequency citation) were independent of their socio-cultural factors, namely age categories, ethnic group, region of residence and gender using Fisher Exact since frequency of some cells was less than 5 [31]. We investigated whether the number of varieties held at household level was correlated to age of the respondent, number of years of experience in pigeonpea cultivation, the size of household and the number of household members engaged in agricultural activities. We analyzed if the number of varieties held by households headed by men and women were different using the non-parametric MannWhitney test since the assumptions of normality were not met [31]. Analyses were done using R 3.2.2 [32].

Distribution and extent of cultivation of different varieties were assessed using the Four Cells Analysis [33]. Thus, in each village, farmers classified existing landraces into four groups using: i) varieties cultivated by many households on large areas; ii) varieties cultivated by many households on small areas; iii) varieties cultivated by few households on large areas, and iv) varieties cultivated by few households on small areas. The four cells analysis has the merit to identify varieties with high demand for livelihood, high demand on the market for quality traits and the rare varieties that should be considered for conservation [16, 17, 34, 35].

\section{Results}

\section{Uses of pigeonpea}

Home consumption and commercialization

All over the study area, $49 \%$ and 39\% of pigeonpea farmers cited home consumption and commercialization respectively as the main reason driving their production of pigeonpea (Fig. 2). In the Department of Couffo, economic reason was the prevailing motive for pigeonpea production. Soil conservation and weed management was the third reason motivating the production of pigeonpea in Departments of Collines, Zou and Plateau (Fig. 2). Besides home consumption, commercialization was the second major purpose for growing pigeonpea in all the surveyed villages. In fact, farmers reported that the income from the sale of pigeonpea grains is used to pay labor at the onset of the cropping season (MarchApril). Thus, pigeonpea plays for the growers a strategic role in the production system. Dry pigeonpea grains are consumed in various forms. Seeds are boiled and mixed with "gari" (cassava derived product) or with maize flour and groundnut oil or palm oil. This form of consumption was the most popular across the surveyed area. In the Department of Plateau, whole dry seeds of pigeonpea are boiled with maize grains and the mixture is eaten with vegetable oil notably oil palm and groundnut oil. Other forms of consumption such as boiled pigeonpea and rice accompanied with sauce were reported. The important place of pigeonpea in home consumption is due to the fact that it is used to make up a shortage of cowpea, maize and other staple foods during lean season (May-June). According to respondents, this role is accounted for by its relatively long storage period, over 6 months.

\section{Medicinal, firewood and fodder}

The uses of pigeonpea plant parts (leaves and stems) depended on the ethnic group or locality of residence of farmers $(P<0.01)$ (Table 1$)$. The leaves were used for feeding animal (goats) especially in the Department of Couffo mainly by Tchi. The use of pigeonpea leaves in folk medicine to cure various diseases was reported all over the study areas but it was predominant in the Departments of Zou and Plateau. Farmers used pigeonpea for medicinal, fodder or firewood regardless of their age and gender $(P>0.05)$ (Table 1$)$. This finding suggests that knowledge related to pigeonpea for medicinal purposes is widely shared within a given community.

Malaria was the most treated disease with pigeonpea and it was reported in all the surveyed villages, with some specificity in regard with the form of administration (Table 2). In regards to specificity in the uses of pigeonpea in folk medicine, the ethnic group Holli in Pobè and Ketou municipalities (South East Benin) used the filtrate obtained after triturating the leaves to treat fever, dizziness and eye infection while the use of leaves was reported in the treatment of measles by ethnic groups Idaatcha, Mahi, Fon and Nago in the Departments of Zou and Collines (Central Benin). The use of pigeonpea leaves in treatment of some ailments was 


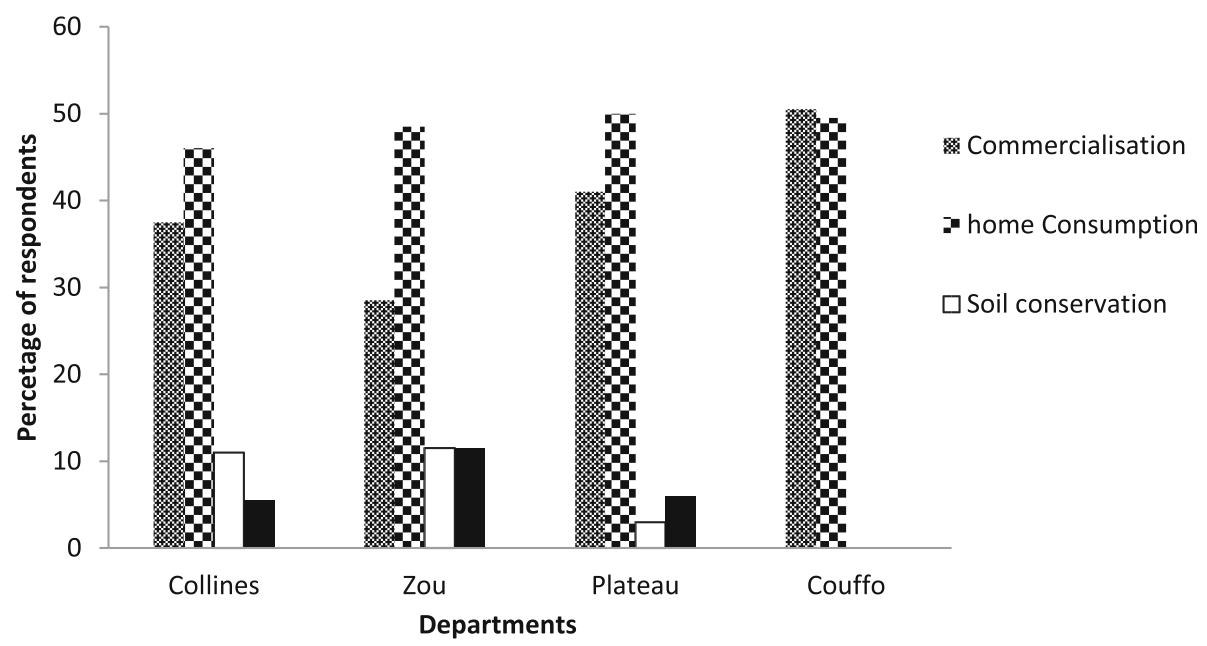

Fig. 2 Reasons of cultivation of pigeonpea across the surveyed areas

locality-dependent (Table 2). This finding revealed that, depending on the locality of residence, farmers hold specific knowledge related to the medicinal uses of pigeonpea. In Wévéhoué village (Department of Couffo), pigeonpea is used in ritual ceremony. Dry pigeonpea seeds are boiled and eaten during twin's naming ceremony. It is worth noting that the different medicinal uses were not associated with a specific pigeonpea variety.

\section{Symbology}

Pigeonpea production in Benin is linked to two key symbols. The most ancient went back to mid-nineteenth century (Story recorded during discussion group organized in March, 2015 in Klouékanmey), and it is related to the name Klouékanmey, a municipality, located in the Department of Couffo (South-West Benin). Klouékanmey in local language "Adja" means "Pigeonpea area". The name was given based on the introduction and cultivation of the crop in this area, which has remained one of the major pigeonpea growing regions in Benin.

Since 2013, a yearly festival is organized in Pobè to celebrate pigeonpea. Thus, each Easter, Pobè people organize a festival to make a showcase of the different pigeonpea based meals and to promote the cultivation of this crop owed to its economic importance for local population. This event named "Odun Otini" in Nago that literally means "Celebration of Pigeonpea" offers a unique opportunity of reunion the member of this community

Table 1 Use frequency of pigeonpea across socio-demographic factors

\begin{tabular}{|c|c|c|c|c|c|}
\hline Socio-demographic factors & & Medicinal & Firewood & Fodder & Probability of Fisher Exact test \\
\hline \multirow[t]{3}{*}{ Age category } & Youth & 9 & 14 & 0 & $P=0.1504$ \\
\hline & Adult & 91 & 183 & 6 & \\
\hline & Old & 8 & 29 & 3 & \\
\hline \multirow[t]{2}{*}{ Gender } & Male & 60 & 133 & 5 & $P=0.8392$ \\
\hline & Female & 48 & 93 & 4 & \\
\hline \multirow[t]{7}{*}{ Ethnic group } & Adja & 24 & 81 & 5 & $P<0.01$ \\
\hline & Fon & 36 & 41 & 0 & \\
\hline & Holli & 10 & 17 & 0 & \\
\hline & Tchi & 1 & 16 & 3 & \\
\hline & Idaatcha & 11 & 17 & 0 & \\
\hline & Nagot & 12 & 30 & 0 & \\
\hline & Mahi & 17 & 22 & 0 & \\
\hline \multirow[t]{4}{*}{ Locality of origin } & Couffo & 24 & 96 & 8 & $P<0.01$ \\
\hline & Plateau & 48 & 59 & 0 & \\
\hline & Zou & 22 & 19 & 0 & \\
\hline & Collines & 17 & 50 & 0 & \\
\hline
\end{tabular}


Table 2 Medicinal uses of pigeonpea

\begin{tabular}{|c|c|c|c|}
\hline Diseases & Forms of use & Form of administration or application & Villages \\
\hline Malaria & $\begin{array}{l}\text { - Triturate the leaves, filter and add lemon juice } \\
\text { - Triturate leaves, and add either lemon or citronella } \\
\text { leaves or both and then filter the mixture } \\
\text { - decoction of pigeonpea leaves and acacia leaves }\end{array}$ & Drinking of the filtrate & All the villages \\
\hline Ulcer & - Leaves decoction & Drinking of the decoction & Zagnanado (Kaodji, Massagbo) \\
\hline Measles (children) & $\begin{array}{l}\text { - Add water to triturated leaves } \\
\text { - Leaves decoction }\end{array}$ & $\begin{array}{l}\text { Use as bath water to treat children } \\
\text { and/or drinking of the decoction }\end{array}$ & $\begin{array}{l}\text { Ouesse (Kokoro), Djidja (Oukpa), } \\
\text { Zagnanado (Kaodji, Massagbo) }\end{array}$ \\
\hline Fever & $\begin{array}{l}\text { - Triturate fresh leaves, add to water and filtrate } \\
\text { - Triturate fresh leaves, filtrate and add to vine or } \\
\text { fermented water }\end{array}$ & $\begin{array}{l}\text { Use as bath water and/or drinking } \\
\text { of the filtrate }\end{array}$ & Pobè (Issaba, Ahoyéyé) \\
\hline Snake bite & Triturate fresh leaves & Apply the triturated leaves on the bite & Djidja (Oukpa, Bowe) \\
\hline Eye infections & - Triturate fresh leaves and filter & Drop the filtrate in eyes & Pobè (Issaba, Ahoyéyé) \\
\hline Dizziness & - Triturate fresh leaves and filter & Drink the filtrate & Pobè (Issaba), Kétou (Mowodani) \\
\hline
\end{tabular}

(Story recorded during group discussion in Pobè in March, 2015). This emphasizes the role of pigeonpea in socio-cultural life of this community and its contribution to build social link.

\section{Folk taxonomy, varieties richness Folk taxonomy}

Farmers in the surveyed areas have local name for pigeonpea (Table 3). The meaning of local name of pigeonpea depended on the ethnic group. The existence of local name of pigeonpea showed the long history of cultivation of the crop and its cultural value in the growing areas.

Varietal naming of pigeonpea based on farmers' knowledge varied across surveyed area but the name of the varieties were either based on the seed color, or the origin of the variety (Adja klui: pigeonpea originated from Adja region), the perception of farmers on the variety (Klui Gbali: simple pigeonpea). Considering the grain color, the literally translated "white pigeonpea" variety was named Otini founfoun, Kolo foufoun, Klouékoun wéwé by Nago/Holli, Idatchaa and Mahi/Fon, respectively. Sixteen varieties were identified of which $5 ; 4 ; 4$ and 3 varieties were recorded in the Departments of Couffo, Plateau, Zou and Collines, respectively. Varietal classification of pigeonpea by producers were based on 8 criteria including morphological (seed colors, seed size, plant height), physiological (maturity groups), agronomic

Table 3 Local names given to pigeonpea and meaning in the different ethnic group

\begin{tabular}{ll}
\hline Ethnic groups & Name \\
\hline Adja and Tchi & Eklui \\
Fon and Mahi & Klouékoun \\
Idaatcha & Kolo \\
Nago from Collines department & Otili \\
Holli and Nago from Plateau department & Otini \\
\hline
\end{tabular}

(productivity, sensitivity to insects attack) and organoleptic and culinary (taste, cooking time).

\section{Varieties richness}

At household level, the number of pigeonpea varieties held by producers ranges from 1 to 3 . Twenty eight percent $(28 \%), 25 \%$ and $13 \%$ of the respondents in the Departments of Plateau, Zou and Collines cultivated two varieties, respectively while in the Department of Couffo each household grew one variety. The highest number of varieties (3) per household was reported in Zou and maintained by only one farmer. There was no significant association $(P>0.05, n=302)$ between the number of varieties held by household and the age of the respondent, number of years of experience in pigeonpea cultivation, the size of household and number of family members engaged in agricultural activities. Similarly, there was no significant $(P>0.05)$ difference between the number of varieties held by men and women (Table 4). None of the socio-cultural factors investigated determined pigeonpea varieties richness at household level.

\section{Distribution and extent of pigeonpea varieties}

The Four Cell Analysis showed that varieties with white primary seed color were the most grown not only in terms of allocated area but also in terms of number of households cultivating them. The varieties with red, spotted, black primary seed color were not preferred by consumers and their production tended to decline. As a result, the following varieties Klouékoun vovo, Klouekoun wlanwlan, Klouékoun, Klui gbali, Adja Kloui, Otini kpoukpa, Otini fifin, Otini doudou, Kolo kpikpa (Fig. 3 a, e, f, g and h) (Table 5) are likely to be totally abandoned by farmers because as previously mentioned, consumers do prefer the white seed varieties to them. Varieties like Kloui gbali grown in Dékandji, Wéwéhoué and klouékoun cultivated in Bayékpa were still being cultivated by many 
Table 4 Relationship between socio-demographic variables and number of pigeonpea varieties held at household level

\begin{tabular}{|c|c|c|c|c|c|}
\hline & & Age of respondent & $\begin{array}{l}\text { Number of years of experience } \\
\text { in pigeonpea cultivation }\end{array}$ & Size of household & $\begin{array}{l}\text { Number of family members } \\
\text { engaged in agricultural activities }\end{array}$ \\
\hline \multirow{2}{*}{ Correlation test } & \multirow{2}{*}{ Number of varieties } & $P=0.179$ & $P=0.619$ & $P=0.4$ & $P=0.263$ \\
\hline & & $R=-0.078$ & $R=-0.029$ & $R=-0.049$ & $R=0.065$ \\
\hline \multirow{3}{*}{ Mann-Whitney test } & Female & 1 (median) & & & \\
\hline & Male & 1 (median) & & & \\
\hline & $\begin{array}{l}W=16,999.0 \\
P=0.9308\end{array}$ & & & & \\
\hline
\end{tabular}

households in these villages because they were the only variety available for farmers. Furthermore, farmers reported the disappearance of some varieties like Adja kloui in Lagbavé, Dékandji and Avéganmè villages and Gbahoun kléli in Dekanji. The abandonment of their production was due to their undesirable traits such as long cooking time, small grains, late maturing, tall plant and low yield (especially for Gbahoun kléli). Recently pigeonpea cultivar named Tagodou (Fig. 3b) with big seeds, high yielding, sweet taste, medium plant height and short cooking time, has been introduced in this area and it is being adopted by farmers leading to the abandonment of the Adja kloui (Fig. 3a) and Gbahoun kléli variety. Adja klui (Fig. 3d) was being cultivated in some villages where it was the only one variety available. This finding suggests that farmers cultivate some pigeonpea landraces because they have limited access to improved varieties. Access to improved varieties could be a threat for the in-situ conservation of these landraces.

\section{Discussion}

\section{Farmers' knowledge on pigeonpea uses}

Pigeonpea is used in various ways. Boiled whole dry seeds were the main form of consumption. Pigeonpea seed boiling was shown to be important in reducing antinutritional factors notably trypsin and increasing digestibility of protein and carbohydrate [36]. The important place of pigeonpea in home consumption is due to the fact that it is used to make up for the shortage of cowpea, maize and other staple foods during lean season (May-June). The use of immature seeds as vegetable was not reported in Benin conversely to what is observed in Eastern African countries and other parts of the world [37-39]. Besides home consumption, commercialization was the second major purpose for growing pigeonpea in all the surveyed villages. Income generated by the sale of pigeonpea grains is used to pay labor at the onset of the cropping season (March-April). This finding underscores the strategic role played by pigeonpea in the production system. Local populations use dry stems and leaves for several purposes (food, firewood, fodder, medicines). This multi-purpose characteristic of pigeonpea, reported across its growing areas worldwide [22], is particularly due to the perennial nature of most of the genotypes [40].

The use of pigeonpea leaves in treatments of some diseases (dizziness, snake bite) was ethnic group and locality-dependent. This finding showed that pigeonpea farmers in Benin do not have the same knowledge on the use of pigeonpea and specific knowledge related to the plant uses might be kept and transmitted within communities in some areas as a result of vertical knowledge transmission $[3,25]$. However, male or female and youths or adults do not hold exclusive knowledge related to the use of pigeonpea for medicinal purposes. This may be a result of horizontal transmission of information among gender and age categories regarding pigeonpea uses $[3,25]$. The use of pigeonpea leaves to treat various diseases such as malaria was reported by farmers in many countries and substantiated by pharmacological or antiviral tests [41-43]. These observations give a scientific support to indigenous knowledge in the identification of plants for treating diseases. The treatment of eye infections and vertigo reported by farmers is confirmed by previous studies [22]. Use of pigeonpea leaves to treat snake bite has not been reported elsewhere. Further researches on the biologically active or the properties of pigeon pea responsible for curing snake bite are needed.

No specific pigeonpea variety was associated with folk medicines conversely to previous findings on Macrotyloma geocarpum (Harms) Maréchal \& Baudet) [18, 44] in Benin and on rice [23] in Nepal, showing that some landraces were specifically used for medicinal purposes. These results suggest that usage of crop varieties in folk medicine depends on the crop species and the cultural background of local communities. Furthermore, the fact that no particular cultural and religious use was associated to a given variety may be a threat for the conservation of grown varieties when new varieties are introduced in the farming systems. In fact, traditional values associated with varieties increase their chance of survival in farming systems [23, 45].

\section{Varieties richness, folk taxonomy, and conservation status of pigeonpea varieties}

Assessing the relationship between socio-cultural factors and varieties richness at household level, no significant 


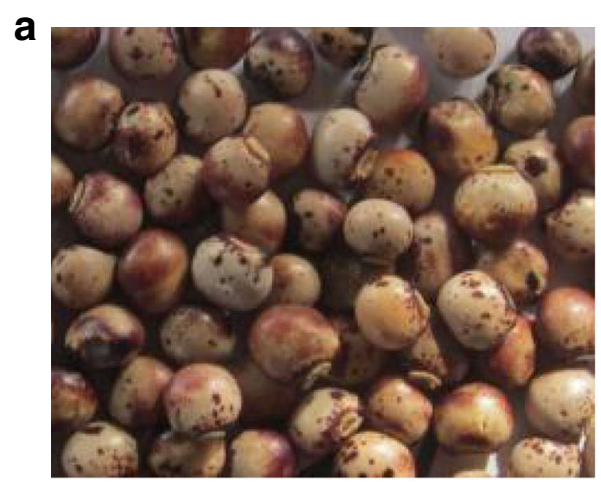

'Klouékoun Wlanwlan'; 'Adja kloui',

c 'Kolo olèyiawo'

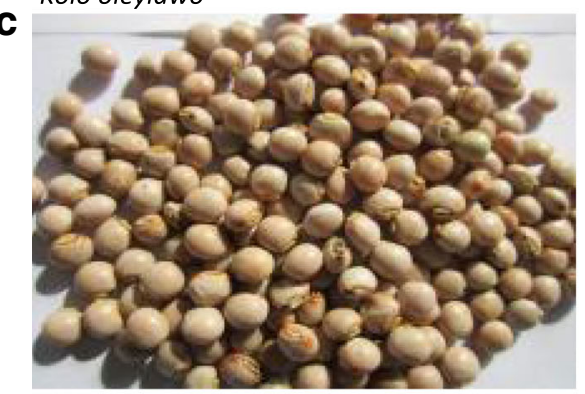

'Klouékoun Wéwé', 'kolo founfoun'

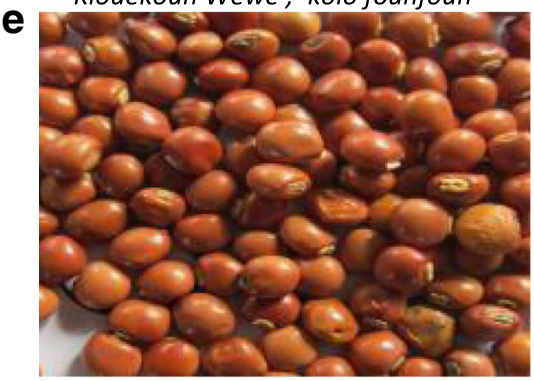

'Klouékoun Vovo'; 'kolo kpikpa', 'otini

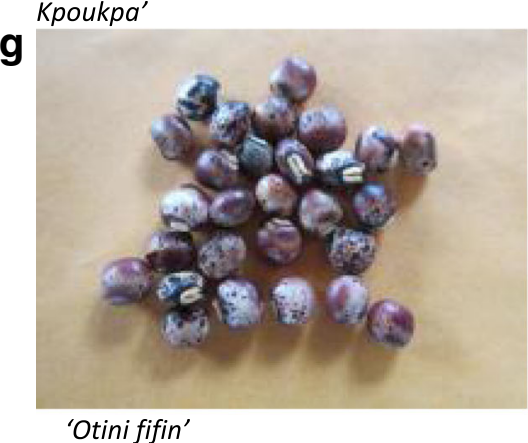

b

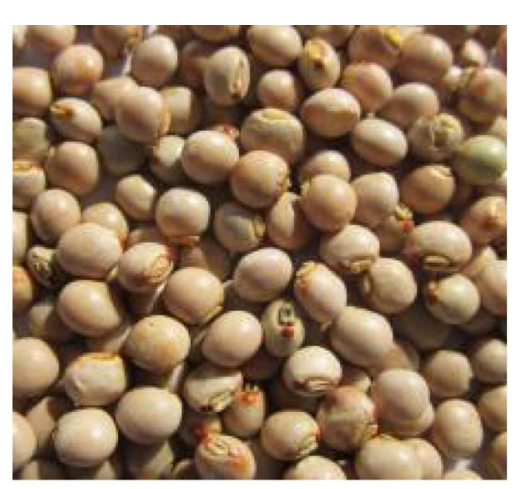

'Tadogou'

d

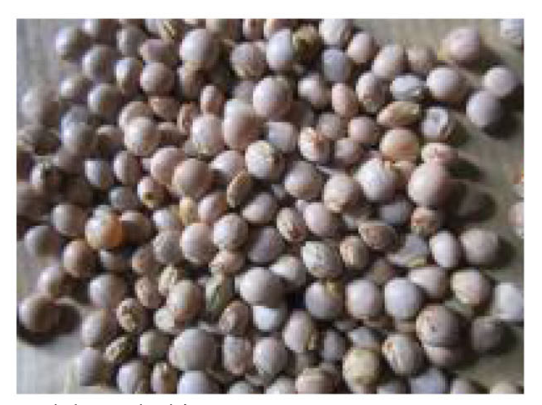

f

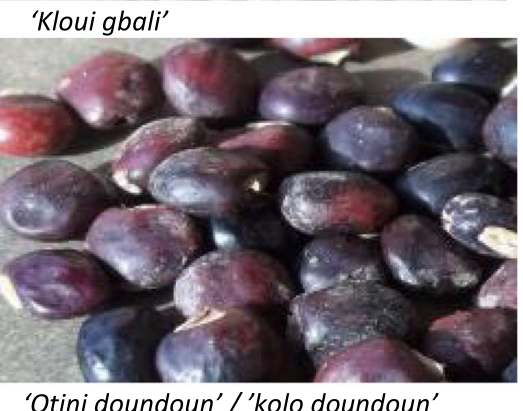

'Otini doundoun' /'kolo doundoun'

h

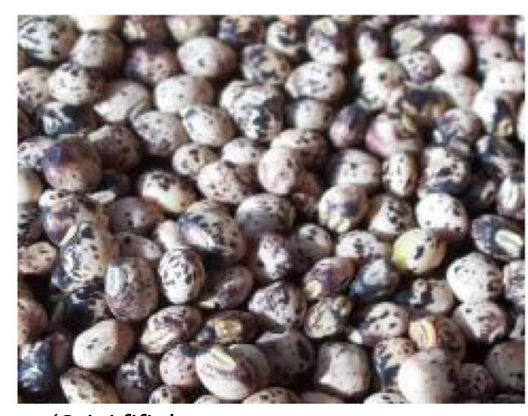

'Otini fifin'

Fig. 3 Common varieties of pigeonpea cultivated in Benin. a Klouékoun Wlanwlan/Adja klouil Kolo olèyiawo; b Tadogou; c: Klouékoun Wéwé/ kolo founfoun; d Kloui gbali; e Klouékoun Vovo/kolo kpikpa/ otini Kpoukpa; f Otini doundoun / kolo doundoun; g Otini fifin; h Otini fifin

association was found between the number of varieties held by household and the age of the respondent, number of years of experience in pigeonpea cultivation, the size of household and number of family members engaged in agricultural activities. This finding does not substantiate our hypothesis and this could be due to the fact that the majority of farmers maintained and cultivated one variety at household level (very low varieties richness). In addition, even though pigeonpea plays an important role in food security, especially during lean season, the crop is not considered by farmers as a priority crop and they do not apply any external inputs and 


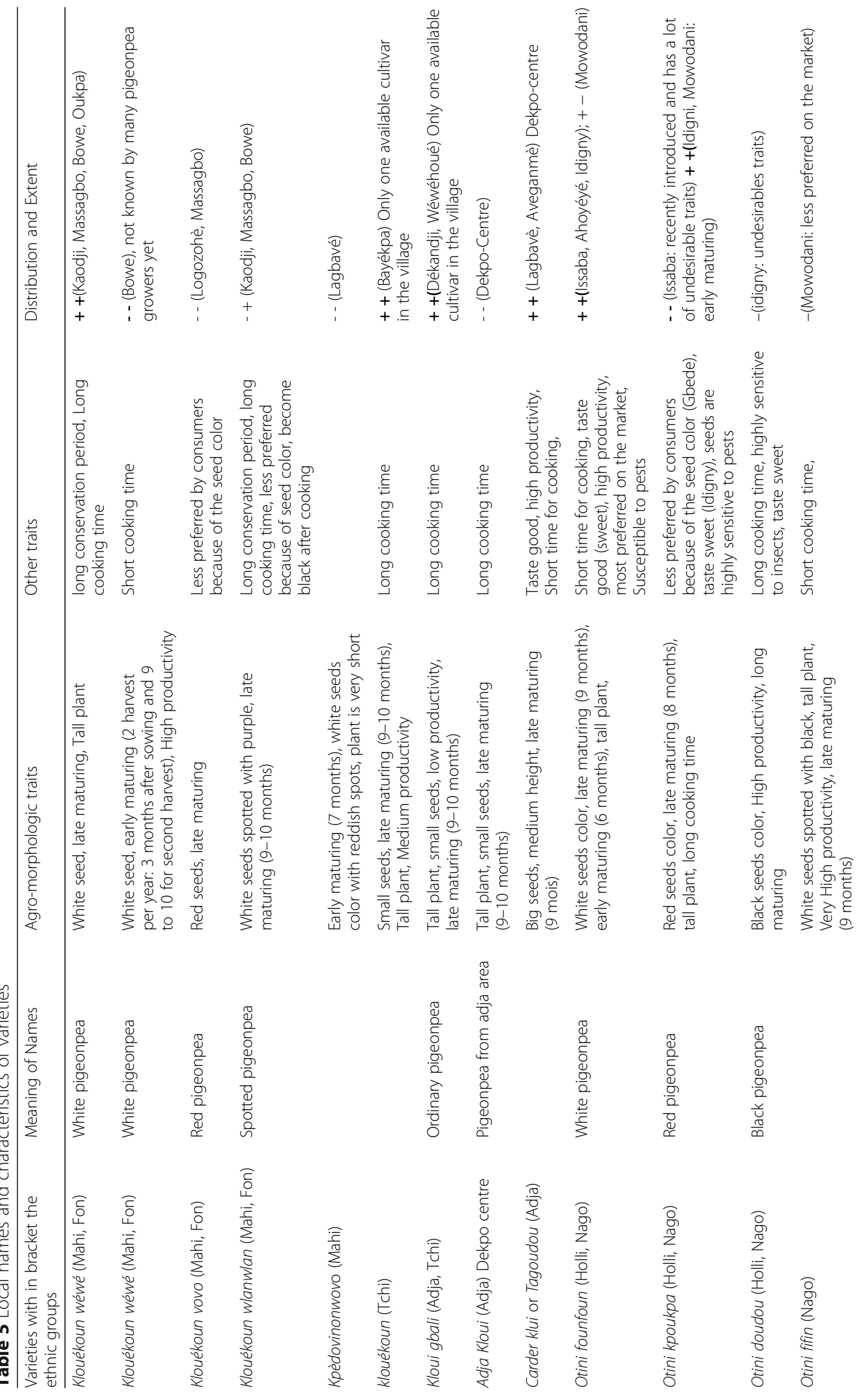




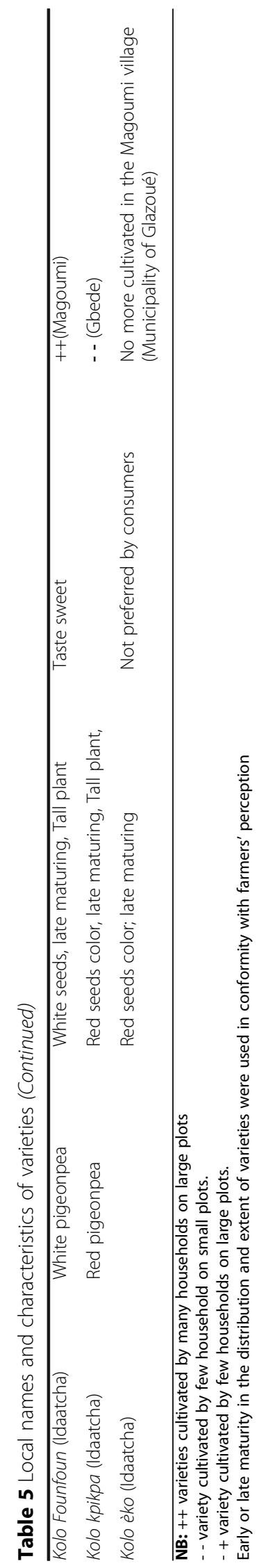


its cultivation does not need special skills. Thus, access to knowledge and resources, which are determined by social cultural and economic factors [3], may not have affected pigeonpea varieties richness. The absence of significant association between gender and diversity maintained at household level agreed with previous finding of Cromwell and Oosterhout [46]. However, Rana et al. [23] reported that male rice growers maintained more rice varieties, while Prain and Piniero [47] found that female farmers contribute more to on farm crop diversity management. All these results suggest that sociocultural contribution to crop diversity maintenance and management is context-based.

Use of morphological, physiological, agronomic and organoleptic traits by farmers to discriminate their varieties was reported in various studies $[19,48]$. Seed color, maturing groups and plant height were the predominant criteria used by farmers in the surveyed regions to classify and identify pigeonpea varieties. Manyasa et al. [39] reported seed size and maturity as the most important criteria used by Ugandan pigeonpea producers to discriminate their varieties while in this study seed color and maturity were the predominant criteria. In fact, farmers use various phenotypic characters to distinguish their varieties and these criteria vary across communities [3]. In this study, eight characters, fewer as compared with internationally described descriptors for pigeonpea, were used by farmers to distinguish the varieties. These criteria may not be enough to effectively differentiate varieties. However, beyond agronomic and morphological traits, farmers used organoleptic and culinary characters, which are not included in the descriptors. Some of the traits (taste of boiled grains) were based on the farmers and consumers preferred straits and they should be considered as breeding objectives in pigeonpea varietal development.

However, varietal taxonomy adopted by pigeonpea farmers depends on ethnic group and farmers' location which may lead to some inconsistency. Therefore, one variety in farmers taxonomy may actually correspond to many varieties (one to multiple) and varieties differently named by farmers may in reality tally to one (multiple to one) $[16,19,48,49]$. Such a situation may contribute to under or over- estimate the diversity within a species. To elucidate the situation, use of various descriptors through agro-morphological characterization back up with molecular tools are recommended [35, 50]. However, high consistency between farmers' varietal classification and molecular markers was reported [11, 51], advising that assessing crop diversity based on folk taxonomy is still to some extent reliable.

In regard to varieties conservation status, varieties with white or cream primary seed color were the most grown not only in terms of allocated area but also in terms of the number of households cultivating. These varieties are not threatened. However, varieties with red, spotted, black primary seed color are not preferred by consumers and their production tends to decline. This observation substantiated findings in similar studies showing the abandonment of varieties farmers found less desirable [11, 37, 52, 53]. The abandonment of less preferred varieties could be explained by the fact that farmers' preferences lie in their desire to adapt to their biophysical environment, cropping systems $[12,53]$ and meet consumers preferences (eg: preference to white seed color) [37, 52, 54]. Despite some undesirable traits mentioned by farmers as reason for their abandonment, these varieties may have some traits that can be exploited in breeding programs for further adaptation. In order to avoid the loss of those varieties, strategies for on farm conservation should be designed. In addition, seed exchange between farmers in the various growing areas should be encouraged with the support of extension agents. In fact, this action lies in the fact that varieties with less preference in some regions may be preferred in others. Furthermore, for ex situ conservation and exploitation of useful traits in Benin pigeonpea germplasm, collection and characterization of the cultivated pigeonpea varieties are advocated.

\section{Conclusion}

Our study revealed that apart from the use of grain, farmers make use of pigeonpea in various ways depending on their ethnic groups and locality. The secondary uses of the crop are rarely mentioned by farmers as variety preference criteria but they can be of importance in the maintenance of plant genetic resource and determine the success of varietal introduction in a given community. Farmers showed a deep knowledge of their grown varieties through folk taxonomy. Medicinal uses of pigeonpea to treat ailments such as dizziness, snake bite, measles are determined by farmers' location and ethnic group. No socio-cultural factor was found to determine maintenance of varieties at household level. Some of the varieties are being abandoned for their undesirable traits and they need to be considered under specific conservation strategy to avoid loss that may hamper future improvement of the crop. We proposed an extensive collection of Beninese pigeonpea genetic resource for further characterization and identification of useful traits to be exploited in the crop improvement programs.

\section{Abbreviations}

INSAE: Institut National de la Statistique et de l'Analyse Economique

\section{Acknowledgements}

The authors gratefully acknowledge the contribution of pigeonpea growers who participated in this research. 


\section{Funding}

Not applicable.

\section{Availability of data and materials}

The datasets supporting the conclusions of this article are included within the article.

\section{Authors' contributions}

MATA designed the study, collected and analyzed data and drafted the manuscript. OK, AEL and DA supervised data analysis and revised the manuscript. All authors read and approved the final manuscript.

\section{Authors' information}

MATA is a Research Assistant at the West Africa Centre for Crop Improvement, University of Ghana.

$\mathrm{AD}(\mathrm{PhD})$ is a lecturer in molecular genetics at University of Ghana, Department of Crop Science and at the West Africa Centre for Crop Improvement (WACCI).

LEA (Dr.) is an Associate Professor in Cropping Systems at University of Abomey-Calavi.

$\mathrm{KO}(\mathrm{PhD})$ is a Professor in plant breeding at the Department of Crop Science, University of Ghana; Legon.

\section{Competing interests}

The authors declare that they have no competing interests.

\section{Consent for publication}

The respondents were informed that their opinions were to be published in a scientific paper and gave their approval.

\section{Ethics approval and consent to participate}

\section{No ethical approval was needed for this study.}

Prior to data collection, participants gave oral consent to participate in the study.

\section{Author details}

${ }^{1}$ Department of Crop Science, School of Agriculture, College of Basic and Applied Sciences, University of Ghana, P. O. Box LG 44, Legon, Ghana. 2Department of Crop Science, Faculty of Agronomic Sciences (FSA), University of Abomey- Calavi, 01 BP 526 Cotonou, Republic of Benin.

Received: 13 April 2017 Accepted: 8 June 2017

Published online: 20 June 2017

\section{References}

1. Sthapit B, Shrestha P, Upadhyay M, editors. On-farm management of agricultural biodiversity in Nepal: good practices. Nepal: NARC/LI-BIRD/ Bioversity International; 2006.

2. Lin BB. Resilience in agriculture through crop diversification: adaptive Management for Environmental Change. Bioscience. 2011;61:183-93.

3. Jarvis DI, Meyer L, Klemick H, Guarino L, Smale M, Brown AHD, et al. A training guide for in situ conservation on-farm. Version 1 [Internet]. Rome: International Plant Genetic Resources Institute; 2000. Available from: http:// www.bioversityinternational.org/fileadmin/_migrated/uploads/tx_news/A_ training_guide_for_In_Situ_conservation_on-farm_611_01.pdf.

4. Hammer K, Teklu Y. Plant genetic resources : selected issues from genetic erosion to genetic engineering. J Agric Rural Dev Trop Subtrop. 2008;109:15-50.

5. Arias-Reyes LM, Belem MO, Brush S, Cuong PH, Dossou B, Eyzaguirre $P$, et al Social, cultural and economic factors and crop genetic diversity. In: Jarvis DI, Meyer L, Klemick H, Guarino L, Smale M, Brown AHD, et al., editors. A Train. Guid. Situ Conserv. On-farm. Version 1. Rome: International Plant Genetic Resources Institute; 2000. p. 11-29.

6. Cocks M. Biocultural diversity: moving beyond the realm of "indigenous" and "local" people. Hum Ecol. 2006;34:185-200.

7. Guarino L. Secondary sources on cultures and indigenous knowledge systems. In: Guarino L, Ramanatha Rao V, Goldberg E, editors. 2011. Collecting Plant Genetic Diversity: Technical Guidelines - 2011 Update. Rome: Bioversity International; 2011. p. 195-228. Available from: http:// cropgenebank.sgrp.cgiar.org/index.php?option=com_content\&view= article\&id=652\&ltemid=864\&lang=english .

8. Pfeiffer JM, Dun S, Mulawarman B, Rice KJ. Biocultural diversity in traditional rice-based agroecosystems: indigenous research and conservation of mavo
(Oryza sativa L.) upland rice landraces of eastern Indonesia. Environ Dev Sustain. 2006;8:609-25.

9. Dixit U, Goyal VC. Traditional knowledge from and for elderly. Indian J Tradit Knowl. 2011;10:429-38.

10. Rudebjer P, Meldrum G, Padulosi S, Hall R, Hermanowicz E. Realizing the promise of neglected and underutilized species.Bioversity International, Rome; 2014. Available from: https://www. bioversityinternational.org/fileadmin/user_upload/online_library/ publications/pdfs/Realizing_the_promise_of_neglected_and_underutilized_ species_1737.pdf

11. Agre AP, Bhattacharjee R, Dansi A, Becerra Lopez-Lavalle LA, Dansi M, Sanni A. Assessment of cassava (Manihot esculenta Crantz) diversity, loss of landraces and farmers preference criteria in southern Benin using farmers' participatory approach. Genet Resour Crop Evol. 2017;64:307-20.

12. Achigan-dako EG, Adjé CA, Danikou SN, Hotegni NVF, Agbangla C, Ahanchédé A. Drivers of conservation and utilization of pineapple genetic resources in Benin. Springerplus. 2014;3:1-11.

13. Keller GB, Mndiga H, Maass BL. Diversity and genetic erosion of traditional vegetables in Tanzania from the farmer's point of view. Plant Genet Resour Charact Util. 2005;3:400-13.

14. Cavatassi R, Hopkins J, Lipper L. The role of crop genetic diversity in coping with agricultural production shocks. Rome: Insights from Eastern Ethiopia [Internet]; 2006. Report No.: 06-17. Available from: http://www.fao.org/3/aah805e.pdf.

15. Ford-Lloyd B, Engels JMM, Jackson M. Genetic resources and conservation challenges under the threat of climate change. In: Jackson M, Ford-Lloyd B, Parry M, editors. Plant Genet. Resour. Clim. Chang; 2013. p. 16-37.

16. Dansi A, Adoukonou-Sagbadja H, Vodouhè R. Diversity, conservation and related wild species of Fonio millet (Digitaria spp.) in the northwest of Benin. Genet. Resour. Crop Evol. 2010;57:827-39.

17. Gbaguidi AA, Dansi A, Loko LY, Sanni A. Diversity and agronomic performances of the cowpea (Vigna unguiculata Walp.) landraces in Southern Benin. Int Res J Agric Sci Soil Sci. 2013;3:121-33.

18. Assogba P, Ewedje E-EBK, Dansi A, Loko YL, Adjatin A, Dansi M, et al. Indigenous knowledge and agro-morphological evaluation of the minor crop Kersting's groundnut (Macrotyloma geocarpum (Harms) Maréchal et Baudet) cultivars of Benin. Genet Resour Crop Evol [Internet]. 2016:63. Springer Netherlands. Available from: http://dx.doi.org/10.1007/s10722-015-0268-9

19. de Haan S. Potato diversity at height: multiple dimensions of farmerdriven in-situ conservation in the Andes. PhD Thesis, Wageningen University; 2009.

20. Dansi A, Vodouhè $R$, Azokpota $P$, Yedomonhan $H$, Assogba $P$, Adjatin $A$, et al. Diversity of the neglected and underutilized crop species of importance in Benin. Sci World J. 2012;2012:19.

21. FAO. The second report on the state of the World's plant genetic resources for food and agriculture. [Internet]. Rome: Food and Agriculture Organization of the United Nations; 2010. Available from: http://www.fao.org/docrep/013/ i1500e/i1500e.pdf

22. Mula MG, Saxena KB. Lifting the level of awareness on pigeonpea - A global perspective [Internet]. Patancheru 502 324, Andhra Pradesh, India: International Crops Research Institute for the Semi-Arid Tropics; 2010. Available from: http://oar.icrisat.org/193/1/296_10_Lifting_eh_level_of_ awareness_on__Pigeonpea.pdf.

23. Rana RB, Garforth C, Sthapit B, Jarvis D. Influence of socio-economic and cultural factors in rice varietal diversity management on-farm in Nepal. Agric Hum Values. 2007;24:461-72.

24. Negash A, Niehof A. The significance of enset culture and biodiversity for rural household food and livelihood security in southwestern Ethiopia. Agric Hum Values. 2004;21:61-71.

25. Leclerc C, D'Eeckenbrugge CG. Social Organization of Crop Genetic Diversity. The G XE × S Interaction Model. Diversity [Internet]. 2012:4:1-32 Available from: http://www.mdpi.com/1424-2818/4/1/1/pdf.

26. INSAE (Institut National de la Statistique et de I'Analyse Economique). Production agricole 2008-2012. 2015. Retrieved from http://www.insae-bj. org/indice-prix-agricoles.html?file=files/stats-economiques/agriculture/ Production\%20Agricole\%202008-2012.xlsx.

27. INSAE (Institut National de la Statistique et de I'Analyse Economique). Principaux indicateurs socio-démographiques et économiques (RGPH-4, 2013) [Internet]. Cotonou: INSAE; 2016. Available from: http://www.insae-bj. org/recensement-population.html?file=files/publications/RGPH4/Principaux Indicateurs\%2Bprojections_PrefaceRGPH4Bon.pdf. 
28. Ayenan MAT. Assessment of phenotypic diversity and farmers' knowledge of cultivation an utilization of pigeon pea (Cajanus cajan (L.) Millspaugh) in Benin. MPhil Thesis, University of Ghana; 2016.

29. Biernacki P, Waldorf D. Snowball Sampling: Problems and Techniques of Chain Referral Sampling. Sociol Methods Res. 1981;10:141-63.

30. Gbedomon RC, Fandohan AB, Salako VK, Idohou RAF, Glèlè Kakaï $R$, Assogbadjo AE. Factors affecting home gardens ownership, diversity and structure : a case study from Benin. Ethnobiol Ethnomed. 2015;11:56.

31. Crawley M. The R book. 2nd ed. West Sussex: Wiley-Blackwell; 2010.

32. R-Core-Team. R: a language and environment for statistical computing. Vienna: R Foundation for Statistical Computing; 2016.

33. Khatiwada SP, Baniya BK, Rijal DK, Paudel CL, Rana RB, Chaudhary P, et al. Population genetic structure. Nepal. In: Jarvis D, Sthapit B, Sears L, editors. Conserv. Agric. Biodivers. Situ a Sci. Basis sustain. Agric. Rome: International Plant Genetic Resources Institute; 2000. p. 134-8.

34. Audi $P$, Nagarajan L, Jones RB. Seed interventions and cultivar diversity in pigeon pea: a farmer based assessment in Eastern Kenya. J New Seeds. 2008;9:111-27.

35. Kombo GR, Dansi A, Loko LY, Orkwor GC, Vodouhè R, Assogba $P$, et al. Diversity of cassava (Manihot esculenta Crantz) cultivars and its management in the Department of Bouenza in the Republic of Congo. Genet Resour Crop Evol. 2012:59:1789-803.

36. Rani S, Jood S, Sehgal S. Cultivar differences and effect of pigeon pea seeds boiling on trypsin inhibitor activity and in vitro digestibility of protein and starch. Food/Nahrung. 1996:40:145-6.

37. Silim SN, Bramel PJ, Akonaay HB, Mligo JK, Christiansen JL. Cropping systems, uses, and primary in situ characterization of Tanzanian pigeonpea (Cajanus cajan (L.) Millsp.) landraces. Genet. Resour. Crop Evol. 2005;52:645-54.

38. Odeny DA. The potential of pigeonpea (Cajanus cajan (L.) Millsp.) in Africa. Nat Resour Forum. 2007:31:297-305.

39. Manyasa EO, Silim SN, Christiansen JL. Variability patterns in Ugandan pigeonpea landraces. J SAT Agric Res. 2009;7:1-9.

40. Daniel JN, Ong CK. Perennial pigeonpea: a multi-purpose species for agroforestry systems. Agrofor Syst. 1990;10:113-29.

41. Aiyeloja AA, Bello OA. Ethnobotanical potentials of common herbs in Nigeria: a case study of Enugu state. Educ Res Rev. 2006;1:16-22.

42. Nwodo UU, Ngene AA, Iroegbu CU, Onyedikachi OAL, Chigor VN, Okoh Al. In vivo evaluation of the antiviral activity of Cajanus cajan on measles virus. Arch Virol. 2011;156:1551-7.

43. Oladunmoye MK, Kehinde FY. Ethnobotanical survey of medicinal plants used in treating viral infections among Yoruba tribe of South Western Nigeria. African J Microbiol Res [Internet]. 2011;5:2991-3004. Available from: http://www.academicjournals.org/article/article1380212319_ Oladunmoye\%20and\%20Kehinde.pdf.

44. Achigan Dako EG, Vodouhè SR. Macrotyloma geocarpum (Harms) Maréchal \& Baudet. In: Brink M, Belay G, editors. PROTA (Plant Resour. Trop. Africa) Ressources végétales I'Afrique Trop. Wageningen; 2006.

45. Bellon MR, Gotor E, Caracciolo F. Assessing the effectiveness of projects supporting on-farm conservation of native crops: evidence from the high andes of South America. World Dev. 2015;70:162-76. Available from: http:// dx.doi.org/10.1016/j.worlddev.2015.01.014

46. Cromwell E, Oosterhout S. On-farm conservation of crop diversity: policy and institutional lessons from Zimbabwe. In: Brush SB, editor. Genes F. On-farm Conserv. Crop Divers. Boca Raton: IPGRI, IDRC, and Lewis Publishers; 2000. p. 217-38.

47. Prain G, Piniero M. Community curatorship of plant genetic resources in southern Philippines: preliminary findings. In: Prain G, Bagalanon C, editors. Local Knowledge, Glob. Sci. Plant Genet. Resour. Towar. A partnership. Proc. an Int. Work. User Particip. Plant Genet. Resour. Res. Dev. May 4-8, 1992. Los Banos: UPWARD; 1994. p. 191-220.

48. Adoukonou-Sagbadja H, Dansi a, Vodouhè R, Akpagana K. Indigenous knowledge and traditional conservation of fonio millet (Digitaria exilis, Digitaria iburua) in Togo. Biodivers Conserv. 2006;15:2379-95.

49. Kamau Jl, Labeyrie V, Njoroge GN, Wanjoya AK, Wambugu PW, Muthamia ZK, et al. Dealing with farmers ' ethnolinguistic differences when collecting crop diversity on-farm; 2016. p. 1-9.

50. Mudaraddi B, Saxena KB. Molecular diversity based heterotic groups in pigeonpea [Cajanus cajan (L.) Millsp.]. Indian J Genet Plant Breed. 2015;75:57.

51. Bajracharya J. Genetic diversity study in landraces of rice (Oryza sativa L.) by agro-morphological characters and mircosatellite DNA markers. PhD Thesis, University of Wale, United Kingdom; 2003.
52. Mergeai G, Kimani P, Mwang A, Olubayo F, Smith C, Audi P, et al. Survey of pigeonpea production systems, utilization and marketing in semi-arid lands of Kenya. Biotechnol Agron Soc Environ. 2001;5:145-53.

53. Lacy SM, Cleveland DA, Soleri D. Farmer choice of sorghum varieties in southern Mali. Hum Ecol. 2006;34:331-53.

54. Høgh-jensen $\mathrm{H}$. To meet future food demands we need to change from annual grain legumes to multipurpose semi-perennial legumes. In: Aladjadjiyan A, editor. Food prod. Approaches, challenges tasks. Rijeka: InTech; 2012. p. 1-24.

\section{Submit your next manuscript to BioMed Central and we will help you at every step:}

- We accept pre-submission inquiries

- Our selector tool helps you to find the most relevant journal

- We provide round the clock customer support

- Convenient online submission

- Thorough peer review

- Inclusion in PubMed and all major indexing services

- Maximum visibility for your research

Submit your manuscript at www.biomedcentral.com/submit
Biomed Central 